\title{
Thymidine kinase/ganciclovir and cytosine deaminase/ 5-fluorocytosine suicide gene therapy-induced cell apoptosis in breast cancer cells
}

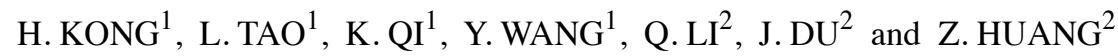 \\ ${ }^{1}$ Department of General Surgery, Nan Shan District People's Hospital, Shenzhen, Guangdong 518052; \\ ${ }^{2}$ Department of General Surgery, Zhujiang Hospital, Southern Medical University, \\ Guangzhou, Guangdong 510282, P.R. China
}

Received February 27, 2013; Accepted May 23, 2013

DOI: $10.3892 /$ or.2013.2562

\begin{abstract}
The present study was conducted to explore the efficacy of suicide gene therapy with thymidine kinase (TK) in combination with cytosine deaminase (CD) for breast cancer. The expression of $\mathrm{CD} / \mathrm{TK}$ was detected in the infected cells by RT-PCR. The killing effect on MCF-7 cells following treatment was analyzed by MTT assay. The morphological characteristics of the cells were observed by electron microscopy, and the distribution of the cell cycle was analyzed by flow cytometry. Caspase- 3 and -8 activities were detected by absorption spectrometry. Cytotoxic assays showed that cells transfected with $\mathrm{CD} / \mathrm{TK}$ became more sensitive to the prodrugs. Morphological features characteristic of apoptosis were noted in the MCF-7 cells via electron microscopy. The experimental data showed that the proportion of MCF-7 cells during the different phases of the cell cycle varied significantly following treatment with the prodrugs. The activity of caspase- 3 gradually increased following treatment with increasing concentrations of the prodrugs. We conclude that the TK/ganciclovir and CD/5-fluorocytosine suicide gene system used here induces apoptosis in breast cancer cells, and provides a promising treatment modality for breast cancer.
\end{abstract}

\section{Introduction}

Breast cancer is the most common malignant tumor noted among women. The incidence rate is consistently increasing with a trend of younger age at diagnosis (1). The incidence of breast cancer involves a complex biological process, and the mechanism involves multi-gene mutations. The current therapeutic strategy for breast cancer consists of comprehensive

Correspondence to: Dr Heng Kong, Department of General Surgery, Nan Shan District People's Hospital, No. 89 Taoyuan Road, Shenzhen, Guangdong 518052, P.R. China

E-mail: generaldoc@126.com

Key words: suicide gene therapy, herpes simplex virus-thymidine kinase, cytosine deaminase, breast cancer treatment modalities that include surgery, chemotherapy, radiotherapy and endocrine therapy. Yet, the rates of recurrence and metastasis are still high. Particularly, patients presenting with advanced stage tumors or those suffering from poor health condition and with a low indication for surgical operation, are in need of effective therapeutic methods. Gene therapy is a promising strategy for the treatment of malignancies. Yet, single suicide gene therapy has drawbacks. Combination gene therapy has the added advantages of gene therapy, elevates therapeutic efficacy and overcomes the shortcomings of single gene therapy $(2,3)$. Thus, combination gene therapy has become a new direction for the development of gene therapy. Cytosine deaminase/5-fluorocytosine (CD/5-FC) and thymidine kinase/ ganciclovir (TK/GCV) are the most common suicide gene therapy treatment systems $(4,5)$. The fusion gene $\mathrm{CD} / \mathrm{TK}$ is a new suicide gene exhibiting better therapeutic effects (6). Based on the the overexpression of the vascular endothelial growth factor (VEGF) in breast cancer cells and the absence of its expression in normal tissues (7-9), the present study applied the CD/TK fusion suicide gene system driven by the VEGF promoter to MCF-7 tumor cells. The adenovirus vector efficiently infected and killed the target cells and induced breast cancer cell apoptosis. The introduction of the VEGF gene promoter ensured the target of the treatment. The present study provides an experimental basis for further application of double suicide gene therapy strategies.

\section{Materials and methods}

Recombinant adenovirus vector. The recombinant adenovirus carrying the VEGF promoter and the CD and TK genes (Ad-VEGFP-CD/TK) was constructed and preserved by our group in the Department of General Surgery,Zhujiang Hospital, Southern Medical University, Guangzhou Guangdong, China. The vector expressing green fluorescence protein was also used. The titer of the purified recombinant adenoviruses was as high as $2.0 \times 10^{11} \mathrm{pfu} / \mathrm{ml}$.

Cells and cell culture. The human breast cancer cell line MCF-7 was obtained from the American Type Culture Collection (ATCC, Manassas, VA, USA). Cell culture medium, 
Dulbecco's modified Eagle's medium (DMEM), fetal bovine serum (FBS), penicillin-streptomycin-glutamine (x100) and $0.5 \%$ trypsin-EDTA solution were purchased from Invitrogen (Carlsbad, CA, USA). As described previously (10), the MCF-7 cell lines were maintained in DMEM supplemented with $10 \%$ FBS, $50 \mathrm{IU} / \mathrm{ml}$ penicillin and $50 \mu \mathrm{g} / \mathrm{ml}$ streptomycin and were grown at $37^{\circ} \mathrm{C}$ in a humidified atmosphere with $5 \% \mathrm{CO}_{2}$.

Transfection. MCF-7 cells were inoculated in 24-well plates at a density of $2 \times 10^{5}$ cells/well. After $12 \mathrm{~h}$, the cells were infected with Ad-VEGFP-CD/TK at multiplicities of infection (MOI) of $1,10,20,40,60,80,100$ and $200 \mathrm{pfu} / \mathrm{cell}$ and then incubated for an additional $48 \mathrm{~h}$. To estimate the optimum MOI of the adenoviral vector in MCF-7 cells, GFP fluorescence was observed under a microscope using a fluorescence light source and a 485-nm filter (Leica, Germany).

Detection of CD/TK gene expression. Expression of the $\mathrm{CD} / \mathrm{TK}$ gene in the infected MCF-7 cells was analyzed by RT-PCR. Total RNA from the treated MCF-7 cells was prepared with TRIzol reagent (Invitrogen, La Jolla, CA, USA) according to the manufacturer's protocol and digested with RNase-free DNase to clear residual genomic DNA. RT-PCR was performed with specific primers from corresponding templates of $\mathrm{CD} / \mathrm{TK}$ (sense, 5'-AGGCTAACAGTGTCGAATAACGCT-3' and antisense, 5'-GTTAGCCTCCCCCATCTC-3') (a DNA fragment of $2,400 \mathrm{bp}$ ). For internal control, $\beta$-actin (sense, 5 -CGGAGTCAA CGGATTTGGTGGTAT-3 and antisense, 5-AGCCTTCTC CATGGTGGTGAAGAC-3) was co-amplified with CD/TK (a DNA fragment of $306 \mathrm{bp}$ ). Before reverse transcription (RT), residual genomic DNA was removed by treatment with RQ DNase (Promega, Madison, WI, USA). Total RNA (750 $\mu \mathrm{g}$ ) was used to synthesize cDNA in $9 \mu \mathrm{l}$ of reaction mixture by standard protocol with oligo $(\mathrm{dT})_{15}$ as primer and AMV reverse transcriptase (Promega). PCR reactions were carried out with $10 \mu 1$ of RT products in $40 \mu 1$ of reaction system using Taq DNA polymerase. After an initial denaturation at $94^{\circ} \mathrm{C}$ for $5 \mathrm{~min}$, 30 cycles of amplification were performed under the following conditions: $94^{\circ} \mathrm{C}$ for $40 \mathrm{sec}, 57^{\circ} \mathrm{C}$ for $60 \mathrm{sec}$ and $72^{\circ} \mathrm{C}$ for $90 \mathrm{sec}$. PCR products were run on $1.5 \%$ agarose gel (containing $0.5 \mathrm{mg}$ of ethidium bromide/liter).

Sensitivity of the cells to GCV and 5-FC. Adenoviral-infected and -uninfected parental cells were plated at a density of $10^{3}$ cells/well with various concentrations $(0.001,0.01,0.1,1$, $10,100$ and $1,000 \mathrm{mg} / \mathrm{l})$ of GCV or various concentrations of $(10,20,40,80,160,320$ and $640 \mathrm{mg} / \mathrm{l}) 5-\mathrm{FC}$ (both from Syntex, Palo Alto, CA, USA) or both agents in 96-well flat-bottomed culture plates (Costar, Bethesda, MD, USA). After incubation for 2 days, the sensitivity of the cells to the prodrugs was evaluated using the tetrazolium salt 3-(4,5-dimethylthiazol2-yl)-2,5-diphenyltetrazolium bromide (MTT) (Sigma, St. Louis, MO, USA) conversion assay. The viability of the cells was determined by comparing the number of viable cells with and without GCV and 5-FC.

Transmission electron microscopy. MCF-7 cells were cultured with the adenoviral vector and the prodrugs and incubated for $48 \mathrm{~h}$ at $37^{\circ} \mathrm{C}$. The cultured cells were harvested using trypsin and centrifuged for $10 \mathrm{~min}$ at $3,500 \mathrm{rpm}$ and room temperature. The pellets were fixed in $4 \%(\mathrm{v} / \mathrm{v})$ glutaraldehyde in $0.1 \mathrm{M}$ coccadylate buffer $(\mathrm{pH} 7.4)$ for $4 \mathrm{~h}$ at $4^{\circ} \mathrm{C}$. The fixed cells were centrifuged and the pellets were blocked in serum which was later fixed in glutaraldeyde overnight at $4^{\circ} \mathrm{C}$. The specimens were washed in three changes of sodium coccadylate buffer ( $\mathrm{pH}$ 7.4) for 10 min each, postfixed in $1 \%$ osmium tetraoxide at $4^{\circ} \mathrm{C}$. The specimens were then washed in three changes of sodium coccadylate buffer ( $\mathrm{pH}$ 7.4) for $10 \mathrm{~min}$ each and dehydrated with a graded series of acetone $(35,50,75,95$ and $100 \%)$. The cells were then infiltrated with acetone and resin and embedded with $100 \%$ resin in beam capsule and left to polymerize at $60^{\circ} \mathrm{C}$ for $48 \mathrm{~h}$. The area of interest in the embedded cell resin block was chosen using the toulidine blue staining and later examined using light microscope. The selected area was cut in ulltrathin sections using an ultramicrotome. The sections were placed into a grid and stained with uranyl acetate for $10 \mathrm{~min}$ followed by $50 \%$ filtered acetone and finally stained using lead which was then washed twice with distilled water. The stained samples were then viewed under transmission electron microscopy (Phillips, Eindhoven, The Netherlands).

Flow cytometric analysis. The experiments were divided into four groups: control group, the low concentration group $(0.1 \mathrm{mg} / \mathrm{l}+40 \mathrm{mg} / \mathrm{l})(\mathrm{GCV}+5-\mathrm{FC})$, the medium concentration group $(1+80 \mathrm{mg} / \mathrm{l})$ and high concentration group $(10+160 \mathrm{mg} / \mathrm{l})$ for $48 \mathrm{~h}$. To quantitatively measure the percentage of cells undergoing apoptosis, $100 \mathrm{ml}$ of the cells $\left(2 \times 10^{5}\right)$ suspended in $1 \mathrm{X}$ binding buffer was transferred to a $5-\mathrm{ml}$ culture tube. Five microliters of FITC-conjugated Annexin $\mathrm{V}$ and $1 \mathrm{ml}$ of $50 \mathrm{mg} / \mathrm{ml}$ PI reagents (Annexin V-FITC kit; BD Pharmingen, USA) were added and then incubated for $15 \mathrm{~min}$ at room temperature in the dark. After the addition of $400 \mathrm{ml} 1 \mathrm{X}$ binding buffer, flow cytometric analysis was performed within $1 \mathrm{~h}$ (FACSCaliber; Becton-Dickinson, USA) according to the manufacturer's instructions (11).

Caspase activity. Caspase- 3 and -8 activities were measured using colorimetric assay kits (R\&D Systems). After transduction of the MCF-7 cells with the adenoviral vector and subsequent incubation with the prodrugs 5-FC and GCV for $48 \mathrm{~h}$, cells were washed with ice-cold PBS, and caspase- 3 and -8 activities were determined using the kit following the manufacturer's recommendations. The control uninfected MCF-7 cells were accepted the same treatment. Caspase colorimetric substrates DEVD-pNA (caspase-3) or IETDpNA (caspase-8) were added to the cell lysate, and assays were performed in a $100-\mu 1$ volume in 96 -well flat-bottomed plates. Chromophore p-nitroanilide was released as a result of cleavage of the substrates by caspase activity. The caspase enzymatic activity in the cell lysate was directly proportional to the chromophore formation, which was quantified spectrophotometrically at a wavelength of $405 \mathrm{~nm}$ using a microplate reader. Data were corrected for the background values that had no substrate or no cell lysate treatment.

\section{Results}

Effective infection of the adenoviral vector in the MCF-7 cells. To determine the infection efficiency of the adenoviral 

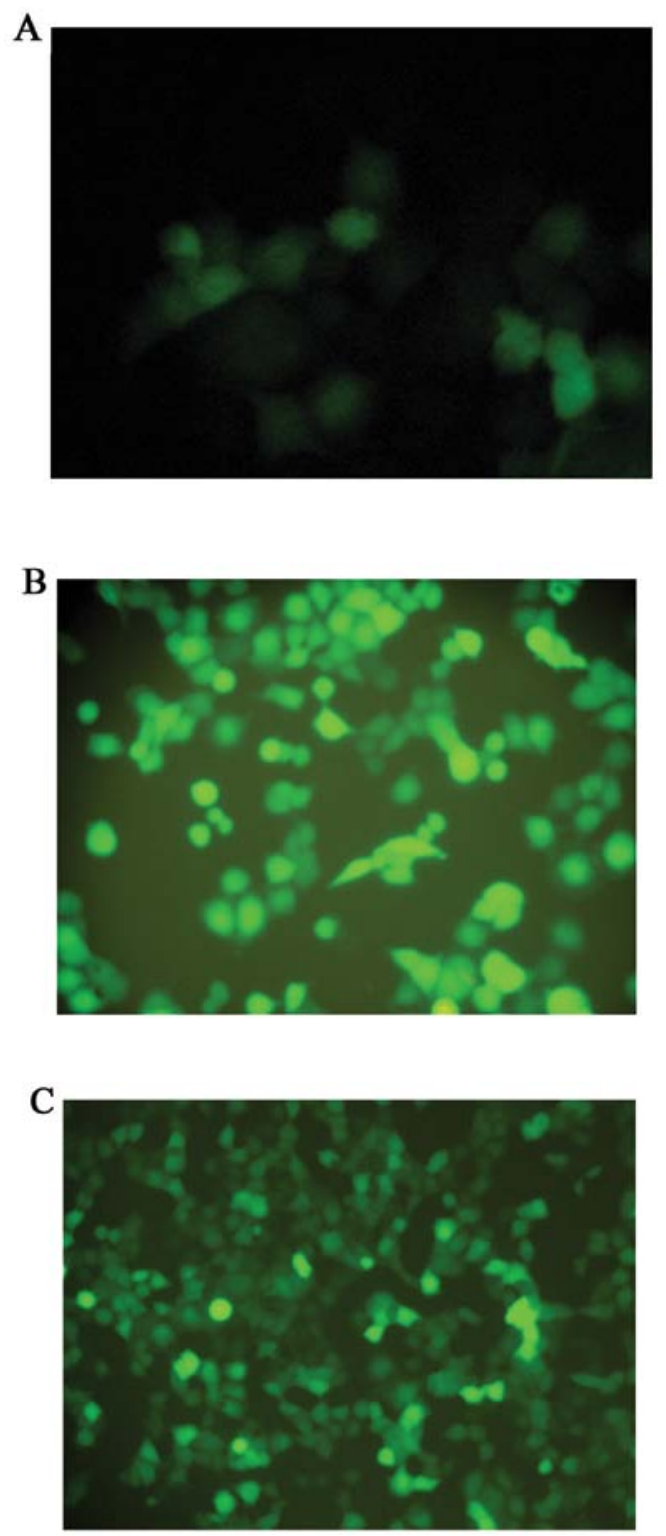

Figure 1. Transient expression of the recombinant GFP genes in MCF-7 cells visualized by fluorescence microscopy (x200). (A) Multiplicities of infection $(\mathrm{MOI})=1 ;(\mathrm{B}) \mathrm{MOI}=100 ;(\mathrm{C}) \mathrm{MOI}=200$.

vector in MCF-7 cells, we infected the MCF-7 cells with the Ad-vector at a MOI ranging from 1 to 200 pfu/cell. Fig. 1 shows different transient expression of the recombinant GFP genes in MCF-7 cells. Preliminary titration revealed a high transfer efficiency of the recombinant adenovirus in MCF-7 cells and an optimal expression at $48 \mathrm{~h}$ post-infection. At a MOI of $100 \mathrm{pfu} / \mathrm{cell},>95 \%$ MCF-7 cells were GFP-positive without obvious adenoviral toxicity (Fig. 1B). Therefore, we performed most of our studies at $48 \mathrm{~h}$ of incubation using the optimal MOI of $100 \mathrm{pfu} / \mathrm{cell}$.

$C D / T K$ gene expression in adv-infected MCF-7 cells. We used RT-PCR to detect the expression of the CD/TK gene. A 2,400-bp fragment of the CD/TK gene was observed, which was consistent with predicted results (Fig. 2). As expected, without $\mathrm{CD} / \mathrm{TK}$ expression, the growth of the parental $\mathrm{MCF}-7$ cells was not infected by the adenoviral vector.

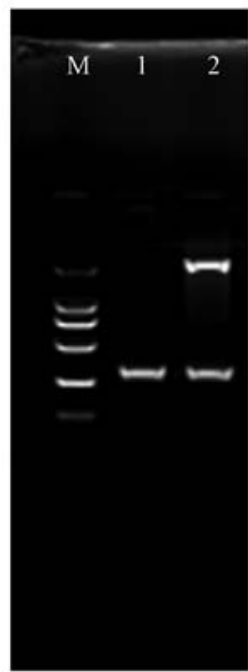

Figure 2. MCF-7 cells were infected with the adenoviral vector. Group 2 was exposed to the adenoviral vector (multiplicities of infection, 100) and group 1 was without the adenoviral vector. After 2 days, RNAs were extracted from the two groups and cytosine deaminase (CD)/thymidine kinase (TK) gene expression was detected by RT-PCR with primers CD/TK (a DNA fragment of $2,400 \mathrm{bp}$ ). For internal control, $\beta$-actin was coamplified with $\mathrm{CD} / \mathrm{TK}$. The amplification product of the $\mathrm{CD} / \mathrm{TK}$ gene was observed in the group infected by the virus but not in the group without virus infection. Lane M, 2,400-bp DNA ladder; lane 1, group without infection; lane 2, group infected with the adenoviral vector.

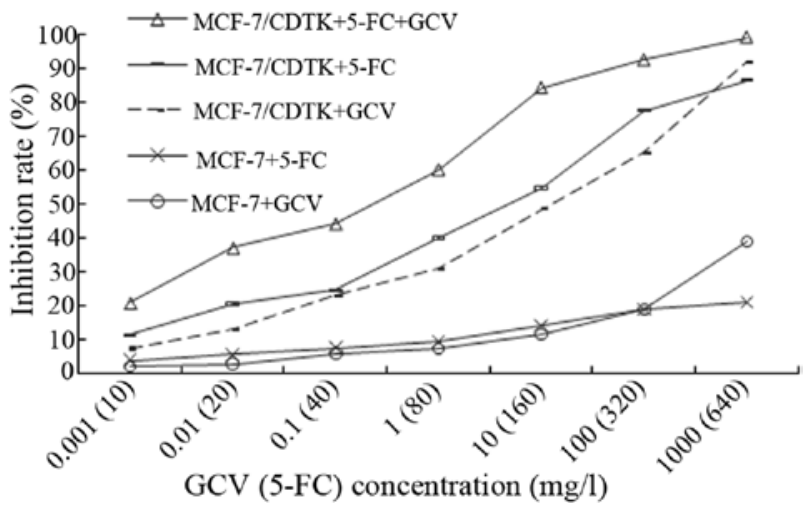

Figure 3. Sensitivity of MCF-7 and MCF-7/CDTK cells to different concentrations of ganciclovir (GCV) and/or 5-fluorocytosine (5-FC).

Cytotoxicity of double suicide gene treatment. To determine whether double prodrugs $(5-\mathrm{FC}+\mathrm{GCV})$ enhance the cytotoxicity of the suicide gene system in vitro, MCF-7 cells were infected with the recombinant adenovirus containing the $\mathrm{CD} / \mathrm{TK}$ fusion gene, and their sensitivity to the prodrugs was compared using MTT assays. As shown in Fig. 3, both prodrugs yielded killing effects on MCF-7/CDTK cells in a concentration-dependent manner. The sensitivity of MCF-7/CDTK cells to $5-\mathrm{FC}+\mathrm{GCV}$ was greater than the sensitivity to 5-FC or GCV alone $(\mathrm{P}<0.01)$. To achieve an equal killing effect, lower doses of $5-\mathrm{FC}+\mathrm{GCV}$ could be used. These results demonstrated that double prodrug therapy was superior to a single prodrug. As shown in Fig. 3, we found that either GCV or 5-FC had no significant effects on the non-infected MCF-7 cells when compared to the experimental group $(\mathrm{MCF}-7 / \mathrm{CDTK}+5-\mathrm{FC} /$ GCV) $(\mathrm{P}<0.01)$. 
Table I. Effects of different concentrations of the prodrugs on the cell cycle and apoptosis of MCF-7/CDTK cells.

\begin{tabular}{|c|c|c|c|c|}
\hline Groups & Apoptotic cells & $\mathrm{G}_{0}-\mathrm{G}_{1}$ & $\mathrm{~S}$ & $\mathrm{G}_{2}-\mathrm{M}$ \\
\hline $0 \mathrm{mg} / 1$ (control group) & $1.11 \pm 0.47$ & $66.91 \pm 3.84$ & $23.91 \pm 1.97$ & $9.45 \pm 0.87$ \\
\hline \multicolumn{5}{|l|}{$\mathrm{GCV}+5-\mathrm{FC}$} \\
\hline $0.1+40 \mathrm{mg} / \mathrm{l}$ & $5.22 \pm 0.52^{\mathrm{a}}$ & $68.57 \pm 6.97$ & $22.46 \pm 2.21$ & $8.10 \pm 0.13^{\mathrm{a}}$ \\
\hline $1+80 \mathrm{mg} / \mathrm{l}$ & $12.07 \pm 1.47^{\mathrm{b}}$ & $77.51 \pm 3.75$ & $19.55 \pm 1.35^{\mathrm{a}}$ & $1.72 \pm 0.28^{\mathrm{b}}$ \\
\hline $10+160 \mathrm{mg} / 1$ & $30.00 \pm 2.96^{\mathrm{b}}$ & $81.48 \pm 5.05^{\mathrm{a}}$ & $17.28 \pm 1.07^{\mathrm{b}}$ & $0.83 \pm 0.18^{b}$ \\
\hline F-value & 170.726 & 5.733 & 9.031 & 260.782 \\
\hline P-value & 0.000 & 0.022 & 0.006 & 0.000 \\
\hline
\end{tabular}

${ }^{\mathrm{a}} \mathrm{P}<0.05 ;{ }^{\mathrm{b}} \mathrm{P}<0.01$, compared with the control group. $\mathrm{CD}$, cytosine deaminase; TK, thymidine kinase; GCV, ganciclovir; 5-FC, 5-fluorocytosine.
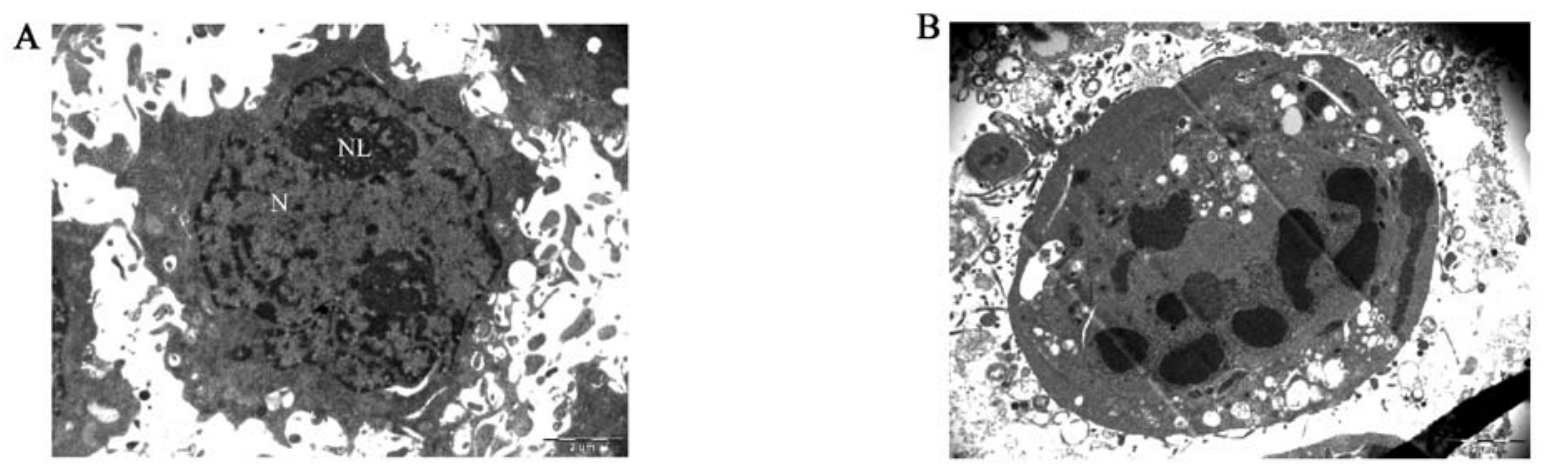

Figure 4. (A) Electromicrograph of untreated MCF-7 human breast cancer cells displays the normal structure of MCF-7 cell. The nucleus (N), nucleolus (NL) and the cytoplasm appeared without abnormal changes (x10,000). (B) Following prodrug-treatment $(48 \mathrm{~h})$ the MCF-7 cells demonstrated morphological feature of late apoptosis: nuclear collapse, continuing blebbing and apoptotic body formation (arrow) (x10,000). Cells were cultured in DMEM (75 ml flask) media and maintained at $37^{\circ} \mathrm{C}$ and $5 \% \mathrm{CO}_{2}$.
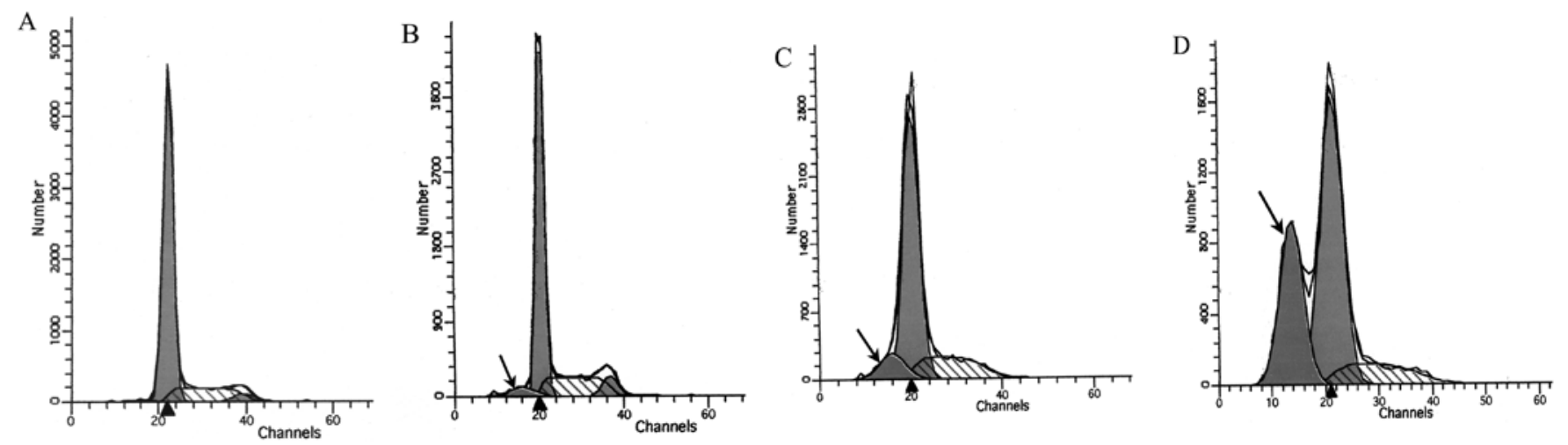

Figure 5. Flow cytometric analysis of the effect of the suicide gene system on MCF-7 cell apoptosis. Apoptotic peak is indicated by the arrowheads. (A) Control group; (B) $0.1+40 \mathrm{mg} / 1$ (GCV+5-FC); (C) $1+80 \mathrm{mg} / 1$; (D) $10+160 \mathrm{mg} / \mathrm{l}$.

Effects of the prodrugs on MCF-7 using transmission electron microscopy. Prodrug-treated MCF-7 cells exhibited cell death corresponding well with the classical features of apoptosis: nuclear collapse, continuing blebbing and apoptotic body formation (Fig. 4B). TEM ultrastructure of untreated MCF-7 cells showed no aberrant structure (Fig. 4A).

Flow cytometric analysis of the cell cycle and apoptosis. Analysis of the cell cycle revealed that the percentage of cells in the $G_{0}-G_{1}$ phase was increased and the percentage of cells in the $G_{2}-M$ and $S$ phase was decreased in the treatment group as detected by flow cytometry. Apoptotic peak was also shown on the leave side of $G_{0}-G_{1}$. The peak became more evident with increasing concentrations of the prodrugs. As shown in Fig. 5 and Table I, the apoptotic peak and cell percentage increased with increasing concentrations of the prodrugs. The effect showed a dose-response relationship. Statistical analysis revealed a significant difference in the numbers of apoptotic cells between the two groups $(\mathrm{P}<0.05)$. 

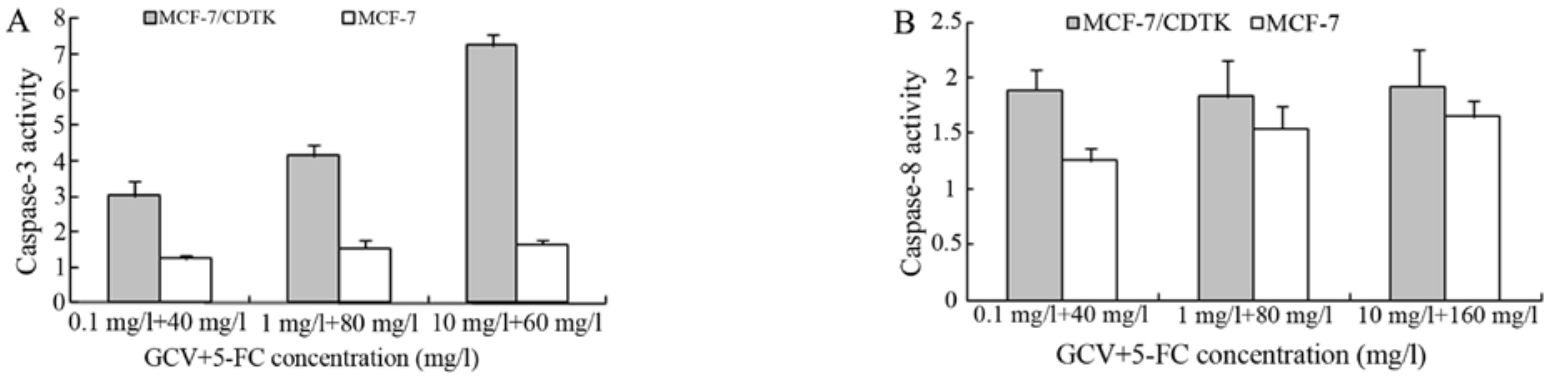

Figure 6. The prodrugs induce an increase in caspase activity in human MCF-7 cells. MCF-7 cell lines were treated with medium only (untreated), $0.1+40 \mathrm{mg} / 1$ (GCV+5-FC), $1+80 \mathrm{mg} / \mathrm{l}, 10+160 \mathrm{mg} / \mathrm{l}$ for $48 \mathrm{~h}$. (A) Caspase-3 and (B) caspase- 8 activities were measured with spectrophotometric methods. The results are expressed as the means \pm SD of three independent experiments. (A) Caspase-3 activity; $\mathrm{P}<0.05$ for experimental groups vs. control group . (B) No significant caspase- 8 activity was noted in the MCF-7 cell lines. Data are representative of one of four similar experiments.

Caspase-3 and - 8 activities. The present study demonstrated that the prodrugs induced apoptosis in the adv-infected MCF-7 cells, and we aimed to ascertain whether this involved caspase-3 or -8 activity. Chromogenic caspase- 3 and -8 substrates were used to directly examine the role of these caspases in the prodrug-treated cells. The activity of caspase-3 (Fig. 6A) was clearly increased following the treatment of MCF-7 cells with GCV and 5-FC. Caspase-3 activity was further significantly increased following the combination treatment of GCV and 5 -FC for $48 \mathrm{~h}$, compared with control alone $(\mathrm{P}<0.05)$. These data suggest that the prodrugs promote double suicide geneinduced apoptosis in MCF-7 cells via a caspase-3-dependent apoptosis pathway. Experimental results showed that caspase-8 was not activated in the prodrug-treated MCF-7 cell lines ( $\mathrm{P}>0.1$ ) compared to the untreated controls (Fig. 6B).

\section{Discussion}

One potential therapeutic strategy for cancer treatment is the technique of inserting suicide genes that activate prodrugs to produce cytotoxity in tumor cells. As previously demonstrated, suicide gene therapy is an effective method for controlling tumor growth, reducing cell survival and eradicating tumors such as schwannoma tumor (12), breast cancer (13), ovarian cancer (14) and lung cancer cell lines (15). For many carcinomas, two such systems, i.e. combination of CD plus 5-FC and herpes simplex virus (HSV)-TK plus GCV have been widely studied $(16,17)$. It is evident that expression of a single transgene is unlikely to be sufficient to eradicate cancer. Numerous studies have demonstrated that HSV-tk combined with cytokine therapy for the treatment of breast carcinoma had a high efficacy (18-21). It has been shown that specific expression of CD or HSV-tk genes in breast as well as other cancer cells can be achieved using a vector delivery system containing VEGF promoter sequences (22). Since breast cancer cell lines exhibit high VEGF expression (23), we constructed an adenovirus-mediated CD/ TK double suicide gene driven by the VEGF promoter. The aim of the present study was to enhance targeting of the vector. The results demonstrated that this vector was capable of directing expression of the $\mathrm{CD} / \mathrm{TK}$ gene in VEGF-expressing breast cells. The double suicide gene system induced the apoptosis of tumor cells infected with the adenovirus vector and when induced by appropriate concentration of 5-FC in conjunction with GCV.

We transferred CD-TK fusion genes into human breast carcinoma cells and investigated the cytotoxic efficacy of
GCV alone, 5-FC alone or the combination of the two prodrugs in vitro. The results showed that each single prodrug killed tumor cells, while the prodrugs in combination had a more powerful killing effect $(\mathrm{P}<0.01)$. In addition, the advantage of the combined treatment with the prodrugs was appreciated by the reduction of drug dose. Taken together, our study demonstrated that strong synergism occurred when tumor cells expressing the CD-TK fusion genes were treated with 5-FC and GCV in combination. Similar to this, the CD-TK fusion gene system used to treat prostate carcinoma cells was previously found to present apparent synergism (24).

Apoptosis is a biological phenomenon that is involved in processes ranging from embryogenesis to ageing, from normal tissue homeostasis to many human diseases including cancer. Apoptotic cells share a number of common features such as cell shrinkage, nuclear condensation, membrane blebbing, chromatin cleavage and formation of pyknotic bodies of condensed chromatin $(25,26)$. These distinctive morphological features form the basis of some of the most widely used techniques for the identification and quantification of apoptosis, and thus morphologic description using light or electron microscopy remains one of the best manners with which to define apoptosis (27). Programmed cell death (apoptosis) compared to necrosis is a desired somatic defense mechanism against cancer cells (28). The double suicide gene system is a promising treatment that possesses the potential to induce apoptosis in different cancer cell lines (29). We found that the $\mathrm{CD} / \mathrm{TK}$ genes induced a marked decrease in cell viability $(92 \%$ in $48 \mathrm{~h})$ in MCF-7 cells at concentrations of 5-FC (320 mg/l) and GCV (100 mg/l) through cell death by apoptosis. The present study was intended to provide evidence of apoptosis in MCF-7 cells induced by the double suicide gene system.

In the present study, the double suicide gene system induced cell cycle arrest and apoptosis. The system reduced the proportion of cells in the $\mathrm{G}_{2}-\mathrm{M}$ and $\mathrm{S}$ phase, and increased those in the $\mathrm{G}_{0}-\mathrm{G}_{1}$ phase. Therefore, our current findings presented in this study suggest that the system induced MCF-7 cell apoptosis by modulating cell cycle progression. Thus, further evaluation of alterations in cell cycle proteins is warranted.

Apoptosis, also known as programmed cell death, refers to certain physiological or pathological conditions in which the end of active cell life is regulated by the activation of a set of apoptotic factors. In normal cells, apoptosis and proliferation coexist and maintain a dynamic equilibrium. It has been reported that HSV-TK/GCV inhibits tumor growth possibly through increased 
caspase-3 expression and induction of apoptosis $(30,31)$. When the CD-TK suicide gene targeting system was delivered into tumor cells, we found that the system significantly inhibited breast cancer cell growth, induced apoptosis in MCF-7 cells, and increased caspase-3 activity (Fig. 6A). Moreover, caspase- 8 activity was not obviously altered (Fig. 6B). These findings indicate that the CD-TK double suicide gene system inhibited cell proliferation via the caspase-3 apoptotic pathway. Therefore, our findings strongly suggest that the VEGF promoter-mediated tumor-targeting suicide gene therapy system may represent a novel therapy for breast cancer.

\section{Acknowledgements}

This work was supported in part by Shenzhen Council for Scientific and Technological Innovation grant of 2013, Shenzhen Nanshan District Science and Technology Project under grant 2012025, and the National High Technology Research and Development Program ('863' Program) of China under grant 2001AA217171.

\section{References}

1. DeSantis C, Siegel R, Bandi P and Jemal A: Breast cancer statistics, 2011. CA Cancer J Clin 61: 409-418, 2011.

2. Liu T, Ye L, He Y, Chen X, Peng J, Zhang X, Yi H, Peng F and Leng A: Combination gene therapy using VEGF-shRNA and fusion suicide gene yCDglyTK inhibits gastric carcinoma growth. Exp Mol Pathol 91: 745-752, 2011.

3. Lee SW, Lee YL, Lee YJ, Park SY, Kim IS, Choi TH, Ha JH, Ahn BC and Lee J: Enhanced antitumor effects by combination gene therapy using MDR1 gene shRNA and HSV1-tk in a xenograft mouse model. Cancer Lett 291: 83-89, 2010.

4. Su GQ, Su G and Huang ZH: Adenovirus-mediated tissuetargeted expression of the CDglyTk gene for the treatment of breast cancer. Mol Med Rep 6: 321-329, 2012.

5. Jia W, Mei L, Wang Y, Liu L and Che G: Double suicide genes selectively kill human umbilical vein endothelial cells. Virol J 8: 74, 2011.

6. Niu HX, Du T, Xu ZF, Zhang XK and Wang RG: Role of wild type $\mathrm{p} 53$ and double suicide genes in interventional therapy of liver cancer in rabbits. Acta Cir Bras 27: 522-528, 2012.

7. Foekens JA, Peters HA, Grebenchtchikov N, Look MP, Meijer-van Gelder ME, Geurts-Moespot A, van der Kwast TH, Sweep CG and Klijn JG: High tumor levels of vascular endothelial growth factor predict poor response to systemic therapy in advanced breast cancer. Cancer Res 61: 5407-5414, 2001.

8. Konecny GE, Meng YG, Untch M, Wang HJ, Bauerfeind I, Epstein M, Stieber P, Vernes JM, Gutierrez J, Hong K, Beryt M, Hepp H, Slamon DJ and Pegram MD: Association between HER-2/neu and vascular endothelial growth factor expression predicts clinical outcome in primary breast cancer patients. Clin Cancer Res 10: 1706-1716, 2004.

9. Linderholm B, Grankvist K, Wilking N, Johansson M, Tavelin B and Henriksson R: Correlation of vascular endothelial growth factor content with recurrences, survival, and first relapse site in primary node-positive breast carcinoma after adjuvant treatment. J Clin Oncol 18: 1423-1431, 2000.

10. Nagaiah K, Venkatesham A, Srinivasa Rao R, Saddanapu V, Yadav JS, Basha SJ, Sarma AV, Sridhar B and Addlagatta A: Synthesis of new cis-fused tetrahydrochromeno [4,3-b] quinolines and their antiproliferative activity studies against MDA-MB-231 and MCF-7 breast cancer cell lines. Bioorg Med Chem Lett 20: 3259-3264, 2010.

11. Kim JE, Chung WY, Chun KS, Lee CK, Park HJ, Kim WB and Park KK: Pleurospermum kamtschaticum extract induces apoptosis via mitochondrial pathway and NAG-1 expression in colon cancer cells. Biosci Biotechnol Biochem 74: 788-792, 2010

12. Mizrak A, Bolukbasi MF, Ozdener GB, Brenner GJ, Madlener S, Erkan EP, Ströbel T, Breakefield XO and Saydam O: Genetically engineered microvesicles carrying suicide mRNA/protein inhibit schwannoma tumor growth. Mol Ther 21: 101-108, 2013.
13. Yi BR, Choi KJ, Kim SU and Choi KC: Therapeutic potential of stem cells expressing suicide genes that selectively target human breast cancer cells: Evidence that they exert tumoricidal effects via tumor tropism (Review). Int J Oncol 41: 798-804, 2012.

14. Hong S, Zhang P, Zhang H, Jia L, Qu X, Yang Q, Rong F and Kong B: Enforced effect of tk-MCP-1 fusion gene in ovarian cancer. J Exp Clin Cancer Res 31: 74, 2012.

15. Cramer F, Christensen CL, Poulsen TT, Badding MA, Dean DA and Poulsen HS: Insertion of a nuclear factor kappa B DNA nuclear-targeting sequence potentiates suicide gene therapy efficacy in lung cancer cell lines. Cancer Gene Ther 19: 675-683, 2012.

16. Luo XR, Li JS, Niu Y and Miao L: Adenovirus-mediated double suicide gene selectively kills gastric cancer cells. Asian Pac J Cancer Prev 13: 781-784, 2012.

17. Zarogoulidis P, Chatzaki E, Hohenforst-Schmidt W, Goldberg EP, Galaktidou G, Kontakiotis T, Karamanos N and Zarogoulidis K: Management of malignant pleural effusion by suicide gene therapy in advanced stage lung cancer: a case series and literature review. Cancer Gene Ther 19: 593-600, 2012.

18. Zhang N, Dong X, Sun Y, Cai X, Zheng C, He A, Xu K and Zheng X: Cytotoxic effects of adenovirus- and lentivirus-mediated expression of Drosophila melanogaster deoxyribonucleoside kinase on Bcap37 breast cancer cells. Oncol Rep 29: 960-966, 2013.

19. Kang NH, Hwang KA, Yi BR, Lee HJ, Jeung EB, Kim SU and Choi KC: Human amniotic fluid-derived stem cells expressing cytosine deaminase and thymidine kinase inhibits the growth of breast cancer cells in cellular and xenograft mouse models. Cancer Gene Ther 19: 412-419, 2012.

20. Li XH, Zhou P, Wang LH, Tian SM, Qian Y, Chen LR and Zhang P: The targeted gene (KDRP-CD/TK) therapy of breast cancer mediated by SonoVue and ultrasound irradiation in vitro. Ultrasonics 52: 186-191, 2012.

21. Joo KM, Park IH, Shin JY, Jin J, Kang BG, Kim MH, Lee SJ, Jo MY, Kim SU and Nam DH: Human neural stem cells can target and deliver therapeutic genes to breast cancer brain metastases. Mol Ther 17: 570-575, 2009.

22. Koshikawa N, Takenaga K, Tagawa M and Sakiyama S: Therapeutic efficacy of the suicide gene driven by the promoter of vascular endothelial growth factor gene against hypoxic tumor cells. Cancer Res 60: 2936-2941, 2000.

23. Radovich M, Hancock BA, Kassem N, Mi D, Skaar TC and Schneider BP: Resequencing of the vascular endothelial growth factor promoter reveals haplotype structure and functional diversity. Angiogenesis 13: 211-218, 2010.

24. Boucher PD, Im MM, Freytag SO and Shewach DS: A novel mechanism of synergistic cytotoxicity with 5-fluorocytosine and ganciclovir in double suicide gene therapy. Cancer Res 66: 3230-3237, 2006.

25. Song NM, Jun S, Zang DY, Kim SG, Park HR and Kang D: Differential susceptibility of gastric cancer cells to TRAILinduced apoptosis. Oncol Rep 29: 1224-1230, 2013.

26. Wang T, D'Souza GG, Bedi D, Fagbohun OA, Potturi LP, Papahadjopoulos-Sternberg B, Petrenko VA and Torchilin VP: Enhanced binding and killing of target tumor cells by drugloaded liposomes modified with tumor-specific phage fusion coat protein. Nanomedicine 5: 563-574, 2010.

27. Terakawa M, Tsuda H, Ashida $\mathrm{H}$ and Sato S: Assessment of tissue alteration in skin after interaction with photomechanical waves used for gene transfection. Lasers Surg Med 42: 400-407, 2010.

28. Mandoky L, Szende B, Géczi L, Bodrogi I, Kásler M and Bak M: Apoptosis regulation and spontaneous apoptosis index of testicular germ cell tumors are associated with differentiation and resistance to systemic treatment. Anticancer Res 28: 1641-1649, 2008.

29. Ortiz R, Prados J, Melguizo C, Rama AR, Alvarez PJ, Rodríguez-Serrano F, Caba O, Boulaiz H and Aranega A: Gef gene therapy enhances the therapeutic efficacy of cytotoxics in colon cancer cells. Biomed Pharmacother 66: 563-567, 2012.

30. Tang W, He Y, Zhou S, Ma Y and Liu G: A novel Bifidobacterium infantis-mediated TK/GCV suicide gene therapy system exhibits antitumor activity in a rat model of bladder cancer. J Exp Clin Cancer Res 28: 155, 2009.

31. Zhang Z, Lin J, Chu J, Ma Y, Zeng S and Luo Q: Activation of caspase-3 noninvolved in the bystander effect of the herpes simplex virus thymidine kinase gene/ganciclovir (HSV-tk/GCV) system. J Biomed Opt 13: 031209, 2008. 